\title{
EFFECT OF WATER IRRIGATION MANAGEMENT AND NITROGEN FERTILIZER SOURCES ON WATER PRODUCTIVITY AND QUALITY OF SOME EGYPTIAN COTTON CULTIVAR
}

\author{
M. M. EL-Sayed ${ }^{1}$, Yasser. A. M. Khalifa ${ }^{2}$ and A. M. M. Elglaly ${ }^{3}$
}

${ }^{1}$ Assoc. Prof., Soil and Water Sci. Dept., Fac. of Ag., Al-Azhar U., Assiut, Egypt.

${ }^{2}$ Assoc. Prof., Agronomy. Dept., Fac. of Ag., Al-Azhar U., Assiut, Egypt.

${ }^{3}$ Lect., Fac. of Ag. Eng. (Assiut Branch), Al-Azhar U., Assiut, Egypt.

Elglalya@yahoo.com

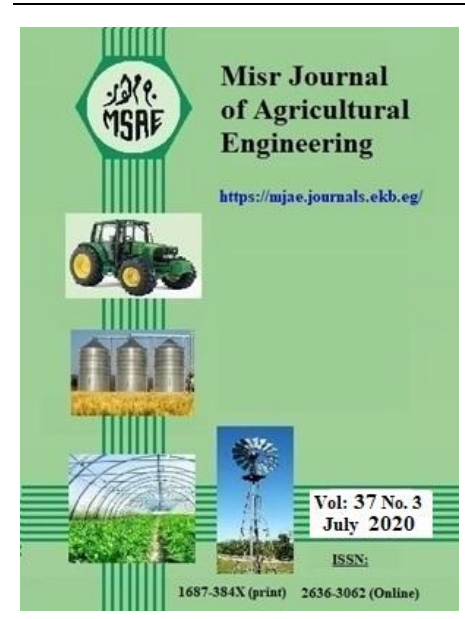

(C) Misr J. Ag. Eng. (MJAE)
Key words:

Evapotranspiration, water consumption, water productivity, quality of yield, cotton.

\begin{abstract}
The experimental field was conducted at the experimental farm, Fac. of Ag., Al-Azhar U., Assuit, during two growing summer seasons of 2018 and 2019. A field experiment was designed as randomized complete block with split split-plot arrangement of treatment with three replications. The current study aims to evaluate different irrigation methods (conventional and alternative furrows) and nitrogen fertilizer Sources (urea as fast nitrogen fertilizer and ureaform as slow one) for maximizing the production of some cotton varieties (G80 and G90) as well as to define the most favorable irrigation manner that achieves the highest water productivity and high cotton yield and its quality. The results showed that alternate furrow irrigation (AFI) saves about $12 \%$ of the actual evapotranspiration $\left(\mathrm{ET}_{\mathrm{a}}\right)$ compared to the conventional furrow irrigation $(\mathrm{CFI})$. The $\mathrm{ET}_{\mathrm{a}}$ increased with urea fertilizer compared to ureaform fertilizer. The estimated evapotranspiration $\left(\mathrm{ET}_{\mathrm{o}}\right)$ values in both growing seasons followed the descending order of FAO Penman-Montithe $>$ Turc $>$ Hargreaves. It is clear that the Hargreaves equation calculated $\mathrm{ET}_{\mathrm{o}}$ efficiently for cotton crop growth under Assiut region circumstances. The AFI increased the crop water productivity (CWP) and irrigation water productivity (IWP) by 13 and $15 \%$, respectively compared to the CFI. The irrigation methods during both growing seasons had significant effects on cotton seed yield, cotton lint percentage, boll weight, lint index, seed index, $2.5 \%$ span length, length uniformity ratio, fiber strength (pressly index) and fiber fineness. The AFI realized positive higher effect on cotton traits and yield quality than those under (CFI).
\end{abstract}

\section{INTRODUCTION}

$\mathrm{I}$ $\mathrm{n}$ many parts of the world, crop production is often constrained by water limitations during the growing season. The distribution and amount of irrigation water together with soil characteristics and evaporation demand, determine the pattern of water availability for plants over time and the ensuring crop biomass and economic yield. The great challenge of the agricultural sector is to produce more food from less water by increasing crop water 
productivity. To optimize crop yields in an irrigated environment, irrigation should be timed in a way that non-productive soil evaporation and drainage losses are minimized. Water deficits should coincide with the least sensitive growth stages of the crop. A full understanding of the trade-offs between yield and water savings when irrigation is withheld early in the season would aid in the design of optimal management strategies (Qureshi et al., 2002 and Sander et al., 2004). At regions with water scarcity, water saving irrigation like alternate furrow irrigation is used for different crops. In furrow irrigation water infiltration in the soil surface layer occurs in horizontal and vertical directions (2-dimensional) and infiltration water front from the two adjacent furrows overlap in horizontal direction. Combined use of alternate furrow irrigation and reduced applied water is considered as water saving or partial root-zone irrigation that enhanced the water productivity (Sepaskhah and Hosseini, 2008).

Egyptian cotton is among the finest cottons in the world. It is not just a crop; it is a history, present, and the future for modern Egypt's renaissance because of its natural and technological features and its superiority to other global cottons. Cotton has in modern years been victim to local and global changes that negatively affected its cultivation and production, the outcome being reduced areas of land planted with cotton. Since cotton was introduced as a commercial crop about a century ago, it has increased in importance until today it is the leading cash crop and the chief item of export. From 80 to 90 percent of all exports are raw cotton, cottonseed, or cottonseed products. The average annual cotton crop amounts to about 1,500,000 bales of 478 pounds net which ranks Egypt as one of the leading cotton-producing countries of the world. Approximately one-third of the average crop is of a staple length of 1.25 inches and over, and the staple of the remainder of the crop, known as Uppers, ranges from $11 / 16$ to $13 / 16$ inches. Egypt is, therefore, the world's chief source of long-staple cotton. In addition to its length, Egyptian cotton is noted for its strength, luster, and silky appearance. These characteristics make it of special value in yarn and fabric when strength and durability are of primary importance. The premiums paid for Egyptian cotton as compared with those paid for other growths indicate the position it holds in the textile world (Abdel-Salam and El-Sayed Negm, 2009).

Ibrahim (2002) reported that irrigation treatments had significant effect on the amount of open bolls /plant, seed cotton yield /plant and seed cotton yield /fed. in both seasons. Cotton plants irrigated at 50\% level of accessible soil moisture gave high open bolls number of /plant, seed cotton yield /plant and seed cotton yield /fed. While, irrigation at 30\%level of accessible soil moisture caused highly significant decrease in boll weight and seed index. Alternative furrow irrigation (AFI) shortened the cotton plant height. (AFI) had insignificant effect on reproductive growth such as bud and boll. AFI reduced 'luxury' transpiration without much reduction in photosynthetic rate, leading to higher water use efficiency (Sheng et al. 2007). Chang et al. (2009) observed that seed cotton yield under Alternative furrow irrigation (AFI) were significantly higher than that under conventional furrow irrigation (CFI).

Cotton water use efficiency realized insignificant differences between conventional furrow irrigation (CFI) and alternative furrow irrigation (AFI). Cotton water use efficiency under (CFI) was higher than that under fixed every-other furrow irrigation (FAFI) by $9.01 \%$ (Ling and Cang 2011). Tafteh and Sepaskhah (2012) found that the cumulative deep percolation 
is lower at variable alternative furrow irrigation (VAFI) and fixed alternative furrow irrigation (FAFI) compared to continuous furrow irrigation (CFI). They also, found that the seasonal deep percolation in rapeseed field was reduced by 39 and 62\% under (VAFI) and (FAFI), respectively compared to (CFI). Therefore, the irrigation method in practice is very important in irrigation management to reduce water losses without yield loss. Compared with conventional irrigation, slight water deficit had no significant effect on cotton yield (Dong et al., 2015).

Abd El-Aal (2014) studied the effect of $\mathrm{N}$ fertilizer rates (45, 60 and $75 \mathrm{~kg} / \mathrm{fed}$ ) on cotton yield, and its components. He indicated that there were significant differences among the three nitrogen levels, in yield and its components. El-Syed et al. (2014) found that the best agriculture management is to use ureaform fertilization since this practice realized the highest wheat production with a good quality. Munir et al. (2015) found that $\mathrm{N}$ rates significantly influenced crop maturity as the node number of first fruiting branch increased with each increase in nitrogen. Also, they found that each nitrogen increment delayed crop flowering.

The current study aims to evaluate different irrigation methods (conventional and alternative furrows) and nitrogen fertilizer sources for maximizing the production of some cotton varieties as well as to define the most favorable irrigation manner the highest water productivity and high cotton yield and its quality.

\section{2- MATERIALS AND METHODS}

The present investigation was carried out at The Experimental Farm, Faculty of Agriculture, Al-Azahar University, Assuit, Egypt which is located around the point of $27^{\circ} 12-16.67=\mathrm{N}$ latitude and $31^{\circ}$ 09- 36.86= E longitude and at $51 \mathrm{~m}$ altitude during the two successive growing seasons of 2018 and 2019. The conducted experiments aimed to study the effects of furrow irrigation method and nitrogen fertilizer Sources on growth, yield, water consumptive use and crop water productivity (CWP) of Egyptian Cotton.

Evapotranspiration (ET) of cotton crop was estimated by some empirical formulas and it was compared with the actual measured (ET). The effects on plant growth parameters, yields and the crop factor $(\mathrm{Kc})$. The experiment was laid out in split split plots design with three replicates and consisted of 8 treatments. The variables were two furrow irrigation method, with two nitrogen fertilizer sources and two varieties of cotton. The main plots were allocated to furrow irrigation method (conventional furrow irrigation (CFI) and alternate furrow irrigation (AFI)) that were bounded with buffer zone of $2 \mathrm{~m}$ width to avoid the horizontal seepage. The split units were assigned for nitrogen fertilizer sources (Urea $46.5 \% \mathrm{~N}$ as a fast nitrogen fertilizer and urea form $40 \% \mathrm{~N}$ as a slow nitrogen fertilizer). The split split plots were devoted to two varieties of cotton (Giza-80 and Giza-90). The area of each plot was 20 $\mathrm{m} 2$ (4 $\mathrm{m}$ in length and $5 \mathrm{~m}$ in width). The cotton seeds were planted on the 20th April of both seasons. The harvesting of cotton plants was practiced 160 days after planting. All the agriculture practices were done as the neighbor farmers do. Cotton fertilization was preformed according to the recommended doses of Ministry of Agriculture (143 kg N/ha, $54 \mathrm{~kg}$ P2O5/ ha. and $57 \mathrm{~kg} \mathrm{~K} 2 \mathrm{O} / \mathrm{ha}$.). Nitrogen in the form of ureaform and phosphorus in the form of single super phosphate were applied in one dose during soil preparation. Nitrogen in the form of urea was divided into two equal doses; the first one was added 20 days after planting. The second dose was added one month later. Potassium in the form of potassium sulfate was 
divided into two equal doses and it added in the time of nitrogen application. The relevant physical and chemical properties of the investigated area were determined according to Page et al. (1982) \& Klute (1986) and they are shown in Table (1) and Table (2).

Table 1: Some soil chemical and physical properties of the experimental site.

\begin{tabular}{|c|c|c|c|c|c|c|c|c|c|}
\hline \multirow{2}{*}{$\begin{array}{l}\text { Soil depth } \\
\quad(\mathrm{cm})\end{array}$} & \multirow{2}{*}{$\begin{array}{l}\text { O.M. } \\
(\%)\end{array}$} & \multirow{2}{*}{$\begin{array}{c}\mathrm{CaCO}_{3} \\
(\%)\end{array}$} & \multirow{2}{*}{$\mathrm{pH}$} & \multirow{2}{*}{$\begin{array}{r}\text { SP } \\
\% \\
\end{array}$} & \multirow{2}{*}{$\begin{array}{r}\mathrm{ECe} \\
(\mathrm{dS} / \mathrm{m})\end{array}$} & \multirow{2}{*}{ SAR } & \multicolumn{3}{|c|}{ Available nutrients (ppm) } \\
\hline & & & & & & & $\mathrm{N}$ & $\mathrm{P}$ & $\mathrm{K}$ \\
\hline $0-30$ & 1.4 & 3.50 & 7.75 & 78 & 1.15 & 4.03 & 74 & 9.60 & 355 \\
\hline $30-60$ & 1.2 & 3.15 & 7.80 & 77 & 1.20 & 4.04 & 69 & 9.40 & 360 \\
\hline
\end{tabular}

O.M. = organic matter $\mathrm{pH}=$ soil reaction $\mathrm{SP}=$ saturation percent $\mathrm{ECe}=$ salinity in soil past extract $\mathrm{SAR}=$ sodium adsorption ratio

Table 2: Some soil physical properties of the experimental site.

\begin{tabular}{|c|c|c|c|c|c|c|c|c|c|c|}
\hline \multirow{2}{*}{$\begin{array}{l}\text { Depth } \\
(\mathrm{cm})\end{array}$} & \multicolumn{3}{|c|}{ Percentage } & \multirow{2}{*}{$\begin{array}{c}\text { Texture } \\
\text { Class }\end{array}$} & \multicolumn{2}{|c|}{$\begin{array}{c}\text { Moisture } \\
\text { content } \theta_{\mathrm{v}} \%\end{array}$} & \multirow{2}{*}{$\begin{array}{l}\text { AW } \\
(\%)\end{array}$} & \multirow{2}{*}{$\begin{array}{c}\mathrm{B}_{\mathrm{d}} \\
\left(\mathrm{g} / \mathrm{cm}^{3}\right)\end{array}$} & \multirow[t]{2}{*}{$\begin{array}{c}\text { Inf. rate } \\
(\mathrm{cm} / \mathrm{h})\end{array}$} & \multirow[t]{2}{*}{$\begin{array}{c}\mathrm{HC} \\
(\mathrm{m} / \text { day })\end{array}$} \\
\hline & Sand & iilt & Clay & & $\mathrm{FC}$ & WP & & & & \\
\hline $0-30$ & 23.50 & 40.25 & 35.25 & Clay Loam & 41 & 21.0 & 20. & 1.27 & \multirow[t]{2}{*}{0.16} & \multirow[t]{2}{*}{0.06} \\
\hline $30-60$ & 24.00 & 40.00 & 36.00 & Clay Loam & 40 & 21.0 & 19 & 1.35 & & \\
\hline
\end{tabular}

F.C. $=$ field capacity, $\quad$ W.P. $=$ wilting point,

Actual consumptive water use (evapotranspiration).

A.W.= available water,

$\mathrm{B}_{\mathrm{d}}=$ bulk density

The amount of water consumed from the root zone between two successive irrigations as a water depth in $\mathrm{cm}$, was calculated from the following equation of Israelsen and Hansen (1962).

$$
\mathrm{CU}=\mathrm{D} \times \mathrm{Pb} \times(\mathrm{Q} 2-\mathrm{Q} 1) / 100
$$

Where:

$\mathrm{CU}=$ actual evapotranspiration. $\quad \mathrm{D}=$ the irrigation soil depth $(\mathrm{cm}) . \mathrm{Pb}=$ bulk density of soil $(\mathrm{gm} / \mathrm{cm} 3) . \quad$ Q2 $=$ the percentage of soil moisture at field capacity. $\quad$ Q1 $=$ the percentage of soil moisture before irrigation.

To obtain the actual water consumptive use (ETa), the soil moisture percentage was determined gravimetrically on dry basis just before and 24 hours after irrigation.

Reference evapotranspiration $\left(\mathrm{ET}_{\mathrm{o}}\right)$

The climatic parameters of the studied area during the two successive growing seasons are presented in table (3).

The $\mathrm{ET}_{\mathrm{o}}$ values were computed from weather data by using some empirical equations as it follows:

FAO Penman-Monteith method:

The reference evapotranspiration $\left(\mathrm{ET}_{\mathrm{o}}\right)$ of individual agro-ecological units are calculated by FAO Penman-Monteith method, using decision support software-CROPWAT 8.0 developed based on FAO Irrigation and Drainage Paper 56 (FAO 1998). The FAO CROPWAT program (FAO, 2009) incorporates procedures for reference crop evapotranspiration and crop water 
requirements and allow the simulation of crop water use under various climate, crop and soil conditions.

Table 3: Average monthly meteorological data of Assiut agrometeological station in the two seasons for Cotton.

\begin{tabular}{|c|l|c|c|c|c|c|c|}
\hline \multirow{5}{*}{ Year } & Month & $\begin{array}{c}\mathrm{T} \text { max } \\
\left({ }^{\circ} \mathrm{C}\right)\end{array}$ & $\begin{array}{c}\mathrm{T} \text { min } \\
\left({ }^{\circ} \mathrm{C}\right)\end{array}$ & $\mathrm{RH} \%$ & $\begin{array}{c}\text { w.s } / \\
\mathrm{km} / \mathrm{h}\end{array}$ & $\begin{array}{c}\text { Sunshine } \\
(\text { hours })\end{array}$ & $\begin{array}{c}\text { Solar } \\
\text { radiation } \\
\left(\mathrm{Mj} / \mathrm{m}^{2} . \mathrm{d}\right)\end{array}$ \\
\hline \multirow{7}{*}{2018} & Apr. & 32.4 & 16.6 & 36.2 & 18.4 & 10.3 & 549 \\
\cline { 2 - 8 } & May & 37.7 & 21.7 & 29.2 & 17.5 & 11.4 & 604 \\
\cline { 2 - 8 } & Jun. & 38.5 & 23.2 & 33.6 & 20 & 12.3 & 639 \\
\cline { 2 - 8 } & Jul. & 38 & 24.7 & 41.5 & 18.7 & 12.2 & 631 \\
\cline { 2 - 8 } & Aug. & 37.6 & 24.3 & 40.7 & 19.8 & 11.9 & 608 \\
\cline { 2 - 8 } & Sep. & 35.5 & 22 & 46.2 & 20.5 & 10.8 & 538 \\
\hline \multirow{3}{*}{2019} & Apr. & 29.6 & 14 & 36.5 & 21.3 & 10.3 & 549 \\
\cline { 2 - 8 } & May & 38.1 & 22 & 28.9 & 18.9 & 11.4 & 604 \\
\cline { 2 - 8 } & Jun. & 39 & 24.9 & 33.9 & 20.3 & 12.3 & 639 \\
\cline { 2 - 8 } & Jul. & 38.9 & 25.2 & 35.1 & 16.8 & 12.2 & 631 \\
\cline { 2 - 8 } & Aug. & 38.9 & 25 & 35.6 & 14.5 & 11.9 & 608 \\
\cline { 2 - 8 } & Sep. & 35.4 & 22.2 & 45.7 & 18.2 & 10.8 & 538 \\
\hline
\end{tabular}

$\mathrm{T}$ Max $=$ Maximum temperature $\left({ }^{\circ} \mathrm{C}\right) \mathrm{T}$ min $=$ Minimum temperature $\left({ }^{\circ} \mathrm{C}\right) \mathrm{RH}=$ Relative humidity $(\%)$ W.S $=$ Wind speed $(\mathrm{Km} / \mathrm{h})$

Hargreaves Method:

According to Jensen et al. (1990) and Allen et al. (1998), the Hargeaves formula was used to estimate the $\mathrm{ET}_{\mathrm{o}}$ as follows:

$$
\mathrm{ET}_{\mathrm{o}}=0.0023 \text { RA TD0.5 }(\mathrm{T}+17.8) \quad \text { mmd-1 }
$$

where:

$\mathrm{RA}=$ extraterrestrial radiation in the equivalent evaporation units, from Table presented by Allen et al. (1998), [mmd-1]

$\mathrm{TD}=$ the difference between mean monthly maximum and mean monthly minimum temperatures, $\left[{ }^{\circ} \mathrm{C}\right] ; \quad \mathrm{T}=$ mean air temperature, $\left[{ }^{\circ} \mathrm{C}\right]$.

Turc Method:

According to Jensen el al. (1990), Turc equation was presented as follows:

For $\mathrm{RH}>50 \%$

$$
\mathrm{ET}_{\mathrm{o}}=0.013(\mathrm{~T} /(\mathrm{T}+15)(\mathrm{Rs}+50)
$$

For $\mathrm{RH}<50 \%$

$$
\mathrm{ET}_{\mathrm{o}}=0.013(\mathrm{~T} /(\mathrm{T}+15)(\mathrm{Rs}+50)\{1+(50-\mathrm{RH}) / 70\}
$$

Where: $\mathrm{T}$ is the average temperature in $\mathrm{oC}$ and $\mathrm{Rs}$ is solar radiation in cal cm-2d-1

Crop coefficient (Kc):

The crop Kc is calculated as the dimensionless ratio of crop $\mathrm{ET}_{\mathrm{a}}$ and the potential $\mathrm{ET}_{\mathrm{o}}$.

$$
\mathrm{Kc}=\mathrm{Et}_{\mathrm{a}} / \mathrm{ET}_{\mathrm{o}}
$$

Where:

$\mathrm{ET}_{\mathrm{a}}=$ actual evapotranspiration measured for the grown crop in mm/day of each month. 
$\mathrm{ET}_{\mathrm{o}}=$ potential evapotranspiration in $\mathrm{mm} /$ day for each month.

Crop water productivity (CWP):

The irrigation water productivity of the marketable yield (seed cotton yield) as Mg seed $\backslash \mathrm{m} 3$ of water were calculated according to Ali et al. (2007) and Ghane et al. (2010) as follows:

Water productivity $(\mathrm{Mg} \mathrm{m}-3)=$

Cotton seed yield in (Mg ha-1) /water consumptive use in (m3 ha-1)

Irrigation water Productivity $(\mathrm{Mg} \mathrm{m}-3)=$

Cotton seed yield (Mg ha-1)/ the irrigation requirement in (m3ha-1)

Yield and quality :

At harvest time, ten cotton plants were chosen randomly from each plot to estimate cotton traits, Also, $4 \mathrm{~m} 2(2 \mathrm{~m} \times 2 \mathrm{~m})$ from each centric area of plot were used to estimate seed and lent yield then expressed by hectar as follows:
1. Cotton seed yield (Mg ha-1).
2. Lint percentage.
3. Boll weight $(\mathrm{g})$.

4. Seed index .

5. Lint index.

6. $2.5 \%$ span length, in m.m.

7. Uniformity index.

8. Fiber strength (pressly index)

9. Micronaire reading.

The data were subjected to analysis of variance (ANOVA) using SPSS Statistics, Version 21.

\section{RESULTS AND DISCUSSION}

\section{1- Actual evapotranspiration $\left(\mathrm{ET}_{\mathrm{a}}\right)$ :}

Actual evapotranspiration (ET $\mathrm{F}_{\mathrm{a}}$ ) as affected by irrigation method and fertilizers types through the growth stages of cottone plants in summer season of 2018 and 2019 is presented in Table (4).The average results of two season as shown in Table (4) The irrigation treatments affected the $\mathrm{ET}_{\mathrm{a}}$ in both seasons since the $\mathrm{ET}_{\mathrm{a}}$ increased under conventional furrow irrigation (CFI). While, the alternate furrow irrigation (AFI) recorded the lowest values of $\mathrm{ET}_{\mathrm{a}}$ in both seasons. The results indicated that $\mathrm{ET}_{\mathrm{a}}$ at the different stages slightly increased in summer season of 2019 compared to that in summer season of 2018. This may be associated to some factors affecting evapotranspiration such as differences in climatic factors between the two seasons or the evaporative power of air. This higher temperature would automatically result in higher water consumptive use. The alternate furrow irrigation method saves about $12 \%$ from $\mathrm{ET}_{\mathrm{a}}$ compared to the conventional furrow irrigation method. This may be due to the lowest area of spreading irrigation water and the lowest wetted area of this method than those in the conventional furrow irrigation method (Ahmad et al., 2009; Ahamd et al., 2011; FAO, 2016; Sarker et al., 2016). The present trend is in harmony with that obtained by Attia $\boldsymbol{e t}$ al. (2015) and Yang et al. (2015). Also, data in Table (4) demonstrated that the $\mathrm{N}$ fertilizer types realized an effect on $\mathrm{ET}_{\mathrm{a}}$. The actual evapotranspiration increased with urea fertilizer compared to ureaform fertilizer. In addition, there were insignificant differences in the actual evapotranspiration between the cotton varieties.

\section{2- Reference evapotranspiration $\left(\mathbf{E T}_{\mathbf{0}}\right)$}

The values of $\mathrm{ET}_{\mathrm{o}}$ were calculated using different empirical equations belongs to different categories of calculation (Table 5). The data showed that the estimated seasonal $\mathrm{ET}_{\mathrm{o}}$ values in both growing seasons followed the descending order of FAO Penman-Montithe > Turc > Hargreaves. The results indicated that the ETo value estimated by FAO Penman-Montithe equation overestimated the ETa by $22.5 \%$ under conventional furrow irrigation (CFI) and 
$32 \%$ under alternate furrow irrigation (AFI) in both seasons. The ETo value estimated by Turc equation overestimated the ETa value by $10.5 \%$ under CFI and 23\% under alternate AFI in both seasons. While the estimated ETo value by Hargreaves equation was less than that of ETa by $23 \%$ under CFI and $8 \%$ under AFI in both seasons.

Table4: Actual evapotranspiration $(\mathrm{mm})$ as affected by irrigation patterns and fertilizers types for different cotton varieties through growth stages during summer season of 2018 and 2019.

\begin{tabular}{|c|c|c|c|c|c|c|c|}
\hline \multicolumn{3}{|c|}{ Treatments } & \multicolumn{4}{|c|}{ Growth stage } & \multirow{2}{*}{$\begin{array}{c}\text { Gross } \\
\text { season } \\
\text { (160 day) }\end{array}$} \\
\hline $\begin{array}{l}\text { Irriga. } \\
\text { method }\end{array}$ & $\begin{array}{c}\text { Fertiliz. } \\
\text { types }\end{array}$ & $\begin{array}{c}\text { cotton } \\
\text { varieties }\end{array}$ & $\begin{array}{c}\text { Initial } \\
\text { (25 day) }\end{array}$ & $\begin{array}{l}\text { Develop. } \\
\text { (50 day) }\end{array}$ & $\begin{array}{l}\text { Mid } \\
(40 \\
\text { day) }\end{array}$ & $\begin{array}{r}\text { End } \\
(45 \\
\text { day) }\end{array}$ & \\
\hline \multicolumn{8}{|c|}{2018} \\
\hline \multirow{4}{*}{ CFI } & $\mathrm{U}$ & G80 & 125 & 300 & 283 & 252 & 960 \\
\hline & & G90 & 125 & 300 & 283 & 252 & 960 \\
\hline & UF & G80 & 125 & 295 & 279 & 248 & 947 \\
\hline & & G90 & 125 & 297 & 276 & 249 & 947 \\
\hline \multirow{4}{*}{ AFI } & $\mathrm{U}$ & G80 & 107 & 264 & 253 & 220 & 844 \\
\hline & & G90 & 107 & 264 & 253 & 220 & 844 \\
\hline & UF & G80 & 107 & 259 & 249 & 216 & 831 \\
\hline & & G90 & 107 & 261 & 246 & 217 & 831 \\
\hline \multicolumn{8}{|c|}{2019} \\
\hline \multirow{4}{*}{ CFI } & $\mathrm{U}$ & G80 & 127 & 305 & 282 & 253 & 967 \\
\hline & & G90 & 127 & 305 & 282 & 253 & 967 \\
\hline & UF & G80 & 127 & 300 & 278 & 249 & 954 \\
\hline & & G90 & 127 & 302 & 275 & 250 & 954 \\
\hline \multirow{4}{*}{ AFI } & $\mathrm{U}$ & G80 & 111 & 267 & 251 & 222 & 851 \\
\hline & & G90 & 111 & 267 & 251 & 222 & 851 \\
\hline & UF & G80 & 110 & 262 & 247 & 218 & 837 \\
\hline & & G90 & 110 & 263 & 244 & 219 & 836 \\
\hline
\end{tabular}

$\mathrm{CFI}=$ conventional furrow irrigation, $\mathrm{AFI}=$ alternate furrow irrigation $\mathrm{U}=$ urea $\mathrm{UF}=$ ureaform $\mathrm{G}=\mathrm{Giza}$

Data of $\mathrm{ET}_{\mathrm{o}}$ values estimated by different empirical equations in both seasons revealed that the $\mathrm{ET}_{\mathrm{o}}$ values started small according to the small plant cover in the early stage. Then, they increased to reach their maximum values in mid-season due to the maximum temperature and plant canopy, and then tended to decline again until the crop maturity due to crop canopy changes. It is clear that the Hargreaves equation calculated $\mathrm{ET}_{\mathrm{o}}$ efficiently for cotton crop growth under Assiut region circumstances.

\section{3-Irrigation requirement}

The amount of seasonal irrigation requirement for different treatments are shown in table (6). The irrigation requirement for cotton crop growth increased under conventional furrow irrigation method (CFI) compared to alternate furrow irrigation method (AFI). The irrigation requirement increased with urea fertilizer compared to ureaform fertilizer. The AFI saved about $14 \%$ from the applied irrigation water compared to the CFI. This may be due to the lowest area of spreading irrigation water and the lowest wetted area of AFI method than those 
in the CFI method. Accepted with Reddi and Reddy (2009), Thind et al. (2010) and Sarker et al. (2016).

Table 5: Calculated reference evapotranspiration $(\mathrm{mm})$ during cotton growth stages using different empirical equations through the growing season of 2018 and 2019

\begin{tabular}{|c|c|c|c|c|c|}
\hline \multirow{2}{*}{ Equation } & \multicolumn{4}{|c|}{ Growth stage } & \multirow{2}{*}{$\begin{array}{c}\text { Gross } \\
\text { season } \\
\text { (160 day) }\end{array}$} \\
\hline & $\begin{array}{c}\text { Initial } \\
\text { (25day) }\end{array}$ & $\begin{array}{l}\text { Develop. } \\
\text { (50 day) }\end{array}$ & $\begin{array}{c}\text { Mid } \\
\text { (40day) }\end{array}$ & $\begin{array}{c}\text { End } \\
\text { (45day) }\end{array}$ & \\
\hline \multicolumn{6}{|c|}{2018} \\
\hline FAO Penman- Monteith & 162 & 410.44 & 338.23 & 328.99 & 1239.65 \\
\hline Hargreaves & 94.7 & 239.49 & 218.05 & 224.64 & 776.88 \\
\hline Turc & 144.55 & 360.32 & 279.46 & 282.35 & 1066.67 \\
\hline \multicolumn{6}{|c|}{2019} \\
\hline FAO Penman- Monteith & 143.53 & 409.73 & 345.2 & 337.24 & 1235.7 \\
\hline Hargreaves & 88.65 & 241.17 & 221.85 & 228.22 & 779.89 \\
\hline Turc & 137.56 & 361.39 & 295.31 & 300.48 & 1094.75 \\
\hline
\end{tabular}

\section{4- Crop water productivity and irrigation water productivity}

Data presented in Table (6) show that the influence of furrow irrigation patterns, fertilizer types and cotton variety on crop water productivity (CWP) and irrigation water productivity (IWP) during 2018 and 2019 seasons. The CWP and IWP increased under alternate furrow irrigation compared to conventional furrow irrigation. The CWP and IWP increased with ureaform fertilizer compared to urea fertilizer. The alternate furrow irrigation method increased the CWP and IWP by 13 and 15\%, respectively compared to the conventional furrow irrigation. The results in agreement with those obtained by Ahmad et al. (2009), Ahamd et al. (2011), Naresh et al. (2012), Attia et al. (2015) and FAO (2016).

\section{5- Crop coefficient $(\mathrm{Kc})$}

For cotton crop under irrigation patterns, the values of Kc were small under all treatments that shortly after the planting (table 7). The Kc started to increase from the initial Kc value at the beginning and reached a maximum value at mid growth stage. During the late season period, as plants being to age, the Kc started again to decrease until it reached a lower value at the end of the growing period. This tendency was obtained for the two growing seasons. The KC values increased under conventional furrow irrigation compared to alternate furrow irrigation. 
Table 6: Irrigation water applied, Water consumptive use, irrigation water productivity and crop water productivity as affected by irrigation patterns and fertilizer types for cotton varieties growth stages during summer season of 2018 and 2019.

\begin{tabular}{|c|c|c|c|c|c|c|}
\hline \multicolumn{3}{|c|}{ Treatments } & \multirow{2}{*}{$\begin{array}{c}\text { Water } \\
\text { consumptive } \\
\text { use }\left(\mathrm{m}^{3} \mathrm{ha}^{-1}\right)\end{array}$} & \multirow{2}{*}{$\begin{array}{l}\text { irrigation } \\
\text { requirement } \\
\left(\mathrm{m}^{3} \mathrm{ha}^{-1}\right)\end{array}$} & \multirow{2}{*}{$\begin{array}{l}\text { crop water } \\
\text { productivity } \\
\left(\mathrm{Mg} \mathrm{m}^{-3}\right)\end{array}$} & \multirow{2}{*}{$\begin{array}{l}\text { irrigation } \\
\text { water } \\
\text { productivity } \\
\left(\mathrm{Mg} \mathrm{m}^{-3}\right)\end{array}$} \\
\hline $\begin{array}{l}\text { Irriga. } \\
\text { Method }\end{array}$ & $\begin{array}{c}\text { Fertiliz. } \\
\text { types }\end{array}$ & $\begin{array}{c}\text { cotton } \\
\text { varietie } \\
\mathrm{s} \\
\end{array}$ & & & & \\
\hline \multicolumn{7}{|c|}{2018} \\
\hline \multirow{4}{*}{ CFI } & \multirow{2}{*}{$\mathrm{U}$} & G80 & 9600 & 12800 & $0.31^{\mathrm{d}}$ & $0.23^{\mathrm{d}}$ \\
\hline & & G90 & 9600 & 12800 & $0.31^{\mathrm{d}}$ & $0.24^{\mathrm{cd}}$ \\
\hline & \multirow{2}{*}{ UF } & G80 & 9470 & 12627 & $0.33^{\mathrm{c}}$ & $0.25^{\mathrm{c}}$ \\
\hline & & G90 & 9470 & 12627 & $0.34^{\mathrm{c}}$ & $0.25^{\mathrm{c}}$ \\
\hline \multirow{4}{*}{ AFI } & \multirow{2}{*}{$\mathrm{U}$} & G80 & 8440 & 10961 & $0.35^{\mathrm{bc}}$ & $0.27^{b}$ \\
\hline & & G90 & 8440 & 10961 & $0.36^{\mathrm{b}}$ & $0.28^{\mathrm{ab}}$ \\
\hline & \multirow{2}{*}{ UF } & G80 & 8310 & 10792 & $0.38^{\mathrm{a}}$ & $0.29^{\mathrm{a}}$ \\
\hline & & G90 & 8310 & 10792 & $0.39^{\mathrm{a}}$ & $0.30^{\mathrm{a}}$ \\
\hline \multicolumn{7}{|c|}{2019} \\
\hline \multirow{4}{*}{ CFI } & \multirow{2}{*}{$\mathrm{U}$} & G80 & 9670 & 12893 & $0.32^{\mathrm{d}}$ & $0.24^{\mathrm{d}}$ \\
\hline & & G90 & 9670 & 12893 & $0.32^{\mathrm{d}}$ & $0.24^{\mathrm{d}}$ \\
\hline & \multirow{2}{*}{ UF } & G80 & 9540 & 12720 & $0.33^{\mathrm{cd}}$ & $0.25^{\mathrm{cd}}$ \\
\hline & & G90 & 9540 & 12720 & $0.34^{\mathrm{c}}$ & $0.26^{\mathrm{c}}$ \\
\hline \multirow{4}{*}{ AFI } & \multirow{2}{*}{$\mathrm{U}$} & G80 & 8510 & 11052 & $0.36^{\mathrm{b}}$ & $0.28^{b}$ \\
\hline & & G90 & 8510 & 11052 & $0.36^{\mathrm{b}}$ & $0.28^{\mathrm{b}}$ \\
\hline & \multirow{2}{*}{ UF } & G80 & 8370 & 10870 & $0.39^{\mathrm{a}}$ & $0.30^{\mathrm{a}}$ \\
\hline & & G90 & 8360 & 10857 & $0.40^{\mathrm{a}}$ & $0.31^{\mathrm{a}}$ \\
\hline
\end{tabular}

$\mathrm{CFI}=$ conventional furrow irrigation, $\quad \mathrm{AFI}=$ alternate furrow irrigation $\mathrm{U}=$ urea $\mathrm{UF}=$ ureaform $\quad \mathrm{G}=$ Giza

In general, the calculated Kc values at different cotton growth stages by various equations were not always identical in both seasons. This may be due to that the differences of the hypothetical reference crop that calculated relative to the crop canopy and aerodynamic resistance were more constant in both growing seasons than hypothetical reference crop that calculated. Accepted with Lal et al. (2012) and Linquist et al. (2015).

\section{6-Cotton yield and quality}

Data in Table (8) showed that the furrow irrigation methods (AFI,CFI) during both growing seasons had significant effects on cotton seed yield, cotton lint percentage, boll weight, lint index and seed index. The alternate furrow irrigation method (AFI) realized positive higher effect on cotton traits and yield than those under conventional furrow irrigation method (CFI). This may be attributed to the better availability of soil moisture during the irrigation cycle for AFI which enhanced water and nutrient uptake and doubtless reflected on final aforementioned criteria. These results are in agreement with those obtained by AbdelMaksoud et al. (2002), Sepaskhah and Khajehabdollahi (2005) Ahamd et al. (2011), Naresh et al. (2012) and FAO (2016). 
Table 7: Cotton crop coefficient for different ETo equations during growth stages as affected by irrigation patterns and fertilizers types at cotton varieties of 2018 and 2019.

\begin{tabular}{|c|c|c|c|c|c|c|}
\hline \multicolumn{2}{|c|}{ Treatments } & \multicolumn{4}{|c|}{ Growth stage } & \multirow{2}{*}{$\begin{array}{c}\text { Gross } \\
\text { season } \\
\text { (160 day) }\end{array}$} \\
\hline $\begin{array}{l}\text { Irriga. } \\
\text { method }\end{array}$ & Equation & $\begin{array}{c}\text { Initial } \\
\text { (25day) }\end{array}$ & $\begin{array}{c}\text { Develop. } \\
\text { (50 day) }\end{array}$ & $\begin{array}{c}\text { Mid } \\
\text { (40da) }\end{array}$ & $\begin{array}{c}\text { End } \\
\text { (45day) }\end{array}$ & \\
\hline \multicolumn{7}{|c|}{2018} \\
\hline \multirow{3}{*}{ CFI } & $\begin{array}{l}\text { FAO Penman- } \\
\text { Monteith }\end{array}$ & 0.77 & 0.73 & 0.83 & 0.76 & 0.77 \\
\hline & Hargreaves & 1.32 & 1.24 & 1.29 & 1.11 & 1.23 \\
\hline & Turk & 0.86 & 0.83 & 1 & 0.89 & 0.89 \\
\hline \multirow{3}{*}{ AFI } & $\begin{array}{l}\text { FAO Penman- } \\
\text { Monteith }\end{array}$ & 0.66 & 0.64 & 0.74 & 0.66 & 0.68 \\
\hline & Hargreaves & 1.13 & 1.09 & 1.15 & 0.97 & 1.08 \\
\hline & Turk & 0.74 & 0.73 & 0.9 & 0.77 & 0.79 \\
\hline \multicolumn{7}{|c|}{2019} \\
\hline \multirow{3}{*}{ CFI } & $\begin{array}{c}\text { FAO Penman- } \\
\text { Monteith }\end{array}$ & 0.88 & 0.74 & 0.81 & 0.75 & 0.78 \\
\hline & Hargreaves & 1.43 & 1.26 & 1.26 & 1.1 & 1.23 \\
\hline & Turk & 0.92 & 0.84 & 0.95 & 0.84 & 0.88 \\
\hline \multirow{3}{*}{ AFI } & $\begin{array}{c}\text { FAO Penman- } \\
\text { Monteith }\end{array}$ & 0.77 & 0.65 & 0.72 & 0.65 & 0.68 \\
\hline & Hargreaves & 1.25 & 1.1 & 1.12 & 0.97 & 1.08 \\
\hline & Turk & 0.8 & 0.73 & 0.84 & 0.73 & 0.77 \\
\hline
\end{tabular}

The $\mathrm{N}$ fertilizer types affected cotton seed yield, cotton lint percentage, boll weight, lint index and seed index. These characters were increased by ureaform fertilizer compared to urea fertilizer. The application of a slow release fertilizer is an effective approach to increasing $\mathrm{N}$ use efficiency, because these fertilizers supply $\mathrm{N}$ on a time schedule that aims to be better synchronized with crop demand, thereby decreasing environmental losses of $\mathrm{N}$. These results are in a harmony with those obtained by Phillip et al (2015). The cotton seed yield, cotton lint percentage, boll weight, lint index and seed index were higher in G90 variety compared to those characters of G80 variety.

\section{7- Cotton quality characters}

Data in table (9) showed that the furrow irrigation methods during both growing seasons had significant effects on $2.5 \%$ span length, length uniformity ratio, fiber strength (pressly index) and fiber fineness. The alternate furrow irrigation (AFI) realized positive higher effect on cotton quality components than those under conventional furrow irrigation (CFI). This may be attributed to the better availability of soil moisture during the irrigation cycle for AFI which reinforce water and nutrient uptake and certainly reflected on final for aforementioned criteria. This result is a good line with that obtained by Abdel-Maksoud et al. (2002), Sepaskhah and Khajehabdollahi (2005 (and Attia et al. (2015). The N fertilizer types showed an effect on $2.5 \%$ span length, length uniformity ratio, fiber strength (pressly index), and fiber fineness since they were increased with ureaform fertilizer compared to those with urea fertilizer. 
Table 8: Yield and yield components as affected by irrigation patterns and fertilizer types for cotton varieties growth stages during summer season of 2018 and 2019.

\begin{tabular}{|c|c|c|c|c|c|c|c|}
\hline & Treatments & & & & & & \\
\hline $\begin{array}{l}\text { Irrigation } \\
\text { method }\end{array}$ & $\begin{array}{l}\text { fertilizers } \\
\text { types }\end{array}$ & $\begin{array}{l}\text { cotton } \\
\text { varieties }\end{array}$ & $\left(\mathrm{Mg} \mathrm{ha}^{-1}\right)$ & percentage & (g) & 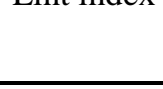 & (g) \\
\hline & & & & 018 & & & \\
\hline & $\bar{U}$ & G80 & $2965^{\mathrm{bc}}$ & $36.0^{\mathrm{d}}$ & $2.3^{\mathrm{c}}$ & $4.20^{\mathrm{c}}$ & $10.5^{\mathrm{bc}}$ \\
\hline & & G90 & $3010^{\mathrm{bc}}$ & $36.6^{\mathrm{c}}$ & $2.5^{\mathrm{b}}$ & $5.10^{\mathrm{a}}$ & $10.7^{\mathrm{b}}$ \\
\hline CFI & UF & G80 & $3150^{\mathrm{a}}$ & $36.8^{c}$ & $2.4^{\mathrm{bc}}$ & $4.00^{\mathrm{d}}$ & $10.8^{\mathrm{ab}}$ \\
\hline & & G90 & $3210^{\mathrm{a}}$ & $37.0^{\mathrm{bc}}$ & $2.7^{\mathrm{a}}$ & $4.58^{\mathrm{b}}$ & $11.0^{\mathrm{a}}$ \\
\hline & $\bar{U}$ & G80 & $2980^{\mathrm{bc}}$ & $37.6^{\mathrm{b}}$ & $2.2^{\mathrm{cd}}$ & $4.61^{b}$ & $10.6^{\mathrm{b}}$ \\
\hline$\Delta \mathrm{FI}$ & & G90 & $3025^{\mathrm{bc}}$ & $38.8^{\mathrm{a}}$ & $2.3^{\mathrm{c}}$ & $4.95^{\mathrm{a}}$ & $10.9^{\mathrm{a}}$ \\
\hline AFI & UF & G80 & $3140^{\mathrm{a}}$ & $38.2^{\mathrm{ab}}$ & $2.4^{\mathrm{bc}}$ & $4.83^{\mathrm{a}}$ & $11.1^{\mathrm{a}}$ \\
\hline & & G90 & $3220^{\mathrm{a}}$ & $39.1^{\mathrm{a}}$ & $2.8^{\mathrm{a}}$ & $4.67^{\mathrm{b}}$ & $11.2^{\mathrm{a}}$ \\
\hline & & & & 019 & & & \\
\hline & $\overline{\mathrm{U}}$ & G80 & $3050^{\mathrm{bc}}$ & $36.5^{\mathrm{d}}$ & $2.2^{\mathrm{c}}$ & $4.73^{\mathrm{a}}$ & $10.4^{\mathrm{bc}}$ \\
\hline & & G90 & $3100^{\mathrm{bc}}$ & $37.0^{\mathrm{cd}}$ & $2.5^{\mathrm{ab}}$ & $4.20^{\mathrm{c}}$ & $10.5^{\mathrm{bc}}$ \\
\hline CFI & UF & G80 & $3190^{\mathrm{ab}}$ & $37.1^{\mathrm{cd}}$ & $2.3^{\mathrm{bc}}$ & $4.61^{\mathrm{a}}$ & $10.6^{\mathrm{b}}$ \\
\hline & & G90 & $3250^{\mathrm{a}}$ & $37.5^{\mathrm{bc}}$ & $2.6^{\mathrm{a}}$ & $4.19^{c}$ & $10.9^{\mathrm{a}}$ \\
\hline & $\mathrm{U}$ & G80 & $3085^{\mathrm{bc}}$ & $38.0^{\mathrm{bc}}$ & $2.4^{\mathrm{b}}$ & $4.42^{\mathrm{b}}$ & $10.6^{\mathrm{b}}$ \\
\hline & & G90 & $3105^{\mathrm{ab}}$ & $39.2^{\mathrm{b}}$ & $2.6^{\mathrm{a}}$ & $4.70^{\mathrm{a}}$ & $10.8^{\mathrm{ab}}$ \\
\hline AFI & UF & G80 & $3225^{\mathrm{a}}$ & $40.1^{\mathrm{a}}$ & $2.5^{\mathrm{ab}}$ & $4.44^{\mathrm{b}}$ & $11.1^{\mathrm{a}}$ \\
\hline & & G90 & $3335^{\mathrm{a}}$ & $40.4^{\mathrm{a}}$ & $2.6^{\mathrm{a}}$ & $4.23^{\mathrm{c}}$ & $11.0^{\mathrm{a}}$ \\
\hline
\end{tabular}

$\mathrm{CFI}=$ conventional furrow irrigation $\mathrm{AFI}=$ alternate furrow irrigation $\mathrm{U}=$ urea $\mathrm{UF}=$ ureaform $\mathrm{G}=\mathrm{Giza}$

Table 9: quality characters as affected by irrigation patterns and fertilizer types for cotton varieties growth stages during summer season of 2018 and 2019.

\begin{tabular}{|c|c|c|c|c|c|c|}
\hline \multicolumn{3}{|c|}{ Treatments } & \multirow{2}{*}{$\begin{array}{c}2.5 \% \text { span } \\
\text { length } \\
(\mathrm{mm})\end{array}$} & \multirow{2}{*}{$\begin{array}{l}\text { Length } \\
\text { uniformity } \\
\text { ratio }\end{array}$} & \multirow{2}{*}{$\begin{array}{c}\text { Fiber } \\
\text { strength } \\
\text { (Pressly } \\
\text { index) }\end{array}$} & \multirow[b]{2}{*}{$\begin{array}{l}\text { Fiber } \\
\text { fineness }\end{array}$} \\
\hline $\begin{array}{l}\text { Irrigation } \\
\text { method }\end{array}$ & $\begin{array}{c}\text { fertilizers } \\
\text { types }\end{array}$ & $\begin{array}{c}\text { cotton } \\
\text { varieties }\end{array}$ & & & & \\
\hline \multicolumn{7}{|c|}{2018} \\
\hline \multirow{4}{*}{ CFI } & $\overline{\mathrm{U}}$ & G80 & $30.5^{\mathrm{b}}$ & $82.4^{\mathrm{b}}$ & $9.9^{\mathrm{a}}$ & $3.8^{\mathrm{b}}$ \\
\hline & & G90 & $29.3^{\mathrm{b}}$ & $81.7^{\mathrm{c}}$ & $9.7^{\mathrm{a}}$ & $3.8^{\mathrm{b}}$ \\
\hline & UF & G80 & $31.4^{\mathrm{ab}}$ & $82.6^{\mathrm{b}}$ & $10.0^{\mathrm{a}}$ & $3.6^{c}$ \\
\hline & & G90 & $29.6^{\mathrm{b}}$ & $82.7^{\mathrm{b}}$ & $9.7^{\mathrm{a}}$ & $4.1^{\mathrm{a}}$ \\
\hline \multirow{4}{*}{ AFI } & $\mathrm{U}$ & G80 & $32.0^{\mathrm{a}}$ & $84.9^{\mathrm{a}}$ & $9.7^{\mathrm{a}}$ & $4.0^{\mathrm{a}}$ \\
\hline & & G90 & $29.9^{\mathrm{b}}$ & $82.0^{\mathrm{bc}}$ & $9.5^{\mathrm{b}}$ & $4.1^{\mathrm{a}}$ \\
\hline & UF & G80 & $32.5^{\mathrm{a}}$ & $83.8^{\mathrm{a}}$ & $9.5^{\mathrm{b}}$ & $4.0^{\mathrm{a}}$ \\
\hline & & G90 & $30.3^{\mathrm{b}}$ & $82.8^{\mathrm{b}}$ & $9.4^{\mathrm{b}}$ & $4.0^{\mathrm{a}}$ \\
\hline \multicolumn{7}{|c|}{2019} \\
\hline \multirow{4}{*}{ CFI } & $\bar{U}$ & G80 & $31.0^{\mathrm{b}}$ & $83.6^{\mathrm{a}}$ & $9.7^{\mathrm{a}}$ & $3.9^{\mathrm{b}}$ \\
\hline & & G90 & $29.0^{\mathrm{c}}$ & $82.1^{\mathrm{b}}$ & $9.5^{\mathrm{a}}$ & $4.0^{\mathrm{b}}$ \\
\hline & $\mathrm{UF}$ & G80 & $32.0^{\mathrm{a}}$ & $83.7^{\mathrm{a}}$ & $9.7^{a}$ & $3.9^{\mathrm{b}}$ \\
\hline & & G90 & $29.1^{\mathrm{c}}$ & $82.4^{\mathrm{b}}$ & $9.6^{\mathrm{a}}$ & $4.2^{\mathrm{ab}}$ \\
\hline \multirow{4}{*}{ AFI } & $\mathrm{U}$ & G80 & $32.7^{\mathrm{a}}$ & $83.7^{\mathrm{a}}$ & $9.5^{\mathrm{a}}$ & $4.0^{\mathrm{b}}$ \\
\hline & & G90 & $30.1^{\mathrm{b}}$ & $82.4^{\mathrm{b}}$ & $9.4^{\mathrm{b}}$ & $4.4^{\mathrm{a}}$ \\
\hline & UF & G80 & $32.6^{\mathrm{a}}$ & $83.8^{\mathrm{a}}$ & $9.3^{\mathrm{b}}$ & $4.3^{\mathrm{a}}$ \\
\hline & & G90 & $30.3^{\mathrm{b}}$ & $82.5^{\mathrm{b}}$ & $9.5^{\mathrm{a}}$ & $4.2^{\mathrm{ab}}$ \\
\hline
\end{tabular}

$\mathrm{CFI}=$ conventional furrow irrigation $\quad \mathrm{AFI}=$ alternate furrow irrigation $\quad \mathrm{U}=$ urea $\quad \mathrm{UF}=$ ureaform $\quad \mathrm{G}=$ Giza 


\section{CONCLUSIONS}

Through this study, we made a comparison between two irrigation pattern namely Conventional furrow irrigation CFI and Alternate furrow irrigation AFI the result showed that AFI treatment controlled stress irrigation without the risk of reduced yield. Moreover, it increased the benefit cost ratio and saved irrigation water. the alternate furrow irrigation the best choice under the conditions of the study area. Also, the application of a slow release fertilizer is an effective approach to increasing $\mathrm{N}$ use efficiency, because these fertilizers supply $\mathrm{N}$ on a time schedule that aims to be better synchronized with crop demand, thereby decreasing environmental losses of $\mathrm{N}$.

\section{REFERENCES}

Abd El-Aal, A.S.A (2014). Effect of some plant densities patterns andnitrogen fertilizer rates on cotton yield, its components and fiberproperties for hybrid cotton 10229 X Giza 86 under early and latesowing. J. Plant Production, Mansoura Univ., 5 (7): 12391258.

Abdel-Maksoud, H.H., Sanaa A. Othman, and A.Y. El-Tawil. (2002). Improving water and $\mathrm{N}$-use utilization for field crops via alternate furrow irrigation technique 1-Maize crop. Mansoura University Journal of Agricultural Sciences Mansoura University 27:8761- 8769.

Abdel-Salam, M.E. and M.A.M. El-Sayed Negm (2009). The Egyptian Cotton; current constraints and future opportunities. Textile Industries Holding Co., Modern PressAlexandria-Egypt

Ahamd, R. N., M. Arshad and M.A. Shahid (2011). Raised Bed Technology for Crop Water Productivity of Maize and Cotton ICID 21st International Congress on Irrigation and Drainage, 15-23 October 2011, Tehran, Iran 171-180.

Ahmad, N., M. Arshad and M.A. Shahid. (2009). Bed-furrow system to replace conventional flood irrigation in Pakistan. Proceedings of 59th IEC Meeting and 20th ICID Conference held at New Dehli, India from December 6-11,

Ali, M.H., M.R. Hoque, A.A. Hassa and A. Khair (2007). Effect of deficit irrigation on yield water productivity and economic returns of wheat. Agric. Water Manag. 92: 151-161.

Allen, R.G.; Pereira, L. S.; Raes, D. and Smith, M., (1998). Crop evapotranspiration: Guidelines for comparing crop water requirements. FAO Irrigation and drainage, Paper No.56. FAO, Rome, Italy. 300pp.

Attia, A.; N. Rajan; Sh.S. Nair; P.B. Delaune; Q. Xue; A.M.H. Ibrahim and D.B. Hays (2015). Modeling cotton lint yield and water use efficiency response to irrigation scheduling using cotton 2K. J. Crop Sci. Society of America. 108 (4): 1614-1623.

Chang, W.Z.; D.T. Sheng; Y.X. Ying and T.Q. Yun (2009). Effects of alternative furrowirrigation on crop water consumption, yield and quality of cotton. Zhongguo 
Shengtai Nongye Xuebao / Chinese J. of Eco-Agric., 17 (1):13-17.

Dong, Zh.X.; Ch. Zhang; Y. Yang; L.H Hong; Y. Zhang and W. Zhang (2015). Water deficit alters cotton canopy structure and increases photosynthesis in the mid-canopy layer. Agron. J., 107 (5): 1947-1957.

El-Sayed M. M., A. I. El-Desoky, A. M. A. Abd El-Monem and M.A. Gameh (2014). Deficit irrigation and nitrogen fertilizers effects on crop production and environment hazardous of nitrate leaching in Upper Egypt. Int. j. Environ. 3(4): 245-255.

FAO (1998). Crop evapotranspiration: Guidelines for computing crop water requirements. FAO irrigation and drainage paper 56. Rome, Italy.

FAO (2009).Cropwat 8.0 for windows user guide. Rome, Italy.

FAO, Food and Agriculture Organisation (2016). Raised beds for improving crop water productivity and water efficiency in irrigated dryland agriculture, Egypt. Technologies and practices for small agricultural producers TECA. Www. teca.fao.org.

Ghane, E., M. Feizi, B.M. Farid and E. Landi (2010). Water productivity of winter wheat in different irrigation planting methods using saline irrigation water Int. J. Agric. Bid. 11: 131-137.

Ibrahim, M.M. (2002). Effect of water supply on growth, yield and fiber properties of cotton plants growth under late sowing conditions. Ph. D. Thesis, Fac. of Agric., Al-Azhar Univ., Egypt.

Israelsen, O.W. and V.E. Hansen (1962). Irrigation principles and practices 3rd Edit. John Willey and Sons. Inc., New York.

Jensen, M. E., R. D. Burman and R. G.Allen, (1990). Evapotranspiration and irrigation water requirements. ASCE Manuals and Reports on Engineering Practices No. 70, Am. Sco. Civil Engrs. New York, NY, 360pp.

Klute, A. (1986). Methods of soil analysis, Part 1: Physical and Mineralogical Methods (2nd) Ed American Soci. of Agronomy, Madison, Wisconsin, USA.

Lal, D., B. Clark, T. Bettner, B. Thoreson and R. L. Snyder (2012). Rice evapotranspiration estimates and crop coefficients in Glenn- Colusa irrigation district, Sacramento Valley, California." Proc., USCID Water Management Conf., USCID, Denver.

Ling, L.P. and ZH.F. Cang (2011). Effect of regulation of water and nitrogen on cotton yield and water use efficiency under different furrow irrigation patterns. J. Cotton Sci., 23 (1): 28-33.

Linquist, B., R. Snyder, F. Anderson, L. Espino, G. Inglese, S. Marras, R. Moratie, R.Mutters, P.Nicolosi, H. Rejmanek, A. Russo, T. Shapland, Z. Song, A. 
Swelam, G.Tindula and J. Hill, (2015). Water balances and evapotranspiration in water and dry seeded rice systems. Irrig. Sci, 33, 375-385.

Munir, M.K.; M. Tahir; M.F. Saleem and M. Yaseen (2015). Growth, yield and earliness response of cotton to row spacing and nitrogen management. J. Anim. Plant Sci. 25(3): 729-738.

Naresh, R.K., B. Singh, S.P. Singh, P.K. Singh, A. Kumar and A. Kumar (2012). Furrow Irrigated Raised Bed (FIRB) Planting Technique for Diversification of Rice-Wheat System for Western IGP Region., Int. J. Life Sc. Bt \& Pharm. Res.1(3): 134-141.

Page, A.L. (Ed.) (1982). Methods of Soil Analysis. Part 1: Physical properties and part 2: Chemical and microbiological properties. (3nded.) Amer. Soc. Agron., In Soil Sci. Soc. Amer. Inc., Madison, Wisconsin, USA.

Phillip, M.C.; Craswell, E.C.; Polidoro, J.C.; Chen, D.L(2015). Fate of efficiency of 15Nlabelled slow-and controlled-release fertilizers. Nutr. Cycl. Agroecosyst., 102, $167-$ 178.

Qureshi ,S.A.; C.A. Madramootoo and G.T. Dodds (2002). Evaluation of irrigation schemes for sugarcane in Sindh, Pakistan , using SWAP93. Agric.Water Manage. 54: $37-48$.

Reddi, G.H.S and T.Y. Reddy (2009). Efficient Use of Irrigation Water. $1^{\text {st }}$ ed. Kalyani Publishers, New Delhi. pp. 110-112.

Sander, J.Z. and W.G.M. Bastianssen (2004). Review of measured crop water productivity values for irrigated wheat, rice, cotton and maize. Agric. Water Manage. 69 (2): 115133.

Sarker, K.K., M. Akanda, R. Biswas, S.K Roy, D.K. Khatun, and M. Goffa. (2016). Field performance of alternate wetting and drying furrow irrigation on tomato crop growth, yield, water use efficiency, quality and profitability. Journal of Integrative Agriculture, 15(10), 2380-2392.

Sepaskhah, A.R., and M.H. Khajehabdollahi (2005). Alternate furrow irrigation with different irrigation intervals for maize (Zea mays L.) Plant Production Science 8:592600 .

Sepaskhah, A.R. and S.N. Hosseini (2008). Effects of alternate furrow irrigation and nitrogen application rates on yield and water- and nitrogen-use efficiency of winter wheat (Triticum aestivum L.). Plant Prod. Sci. 11 (2): 250-259.

Sheng, D.T.; K.Sh. Zhong; W.Zh. Chang; W. Feng; Y.X. Ying and S.X. Li (2007). Responses of cotton growth, yield, and water use efficiency to alternate furrow irrigation. J. Acta Agron. Sinica, 33 (12):1982-1990.

Tafteh ,A. and A. R. Sepaskhah (2012). Application of HYDRUS-1D model for simulating 
water and nitrate leaching from continuous and alternate furrow irrigated rapeseed and maize fields. Agric. Water Manage. 113: 19-29.

Thind, H. S.; G. S. Buttar and M. S. Aujla (2010). Yield and water use efficiency of wheat and cotton under alternate furrow and check-basin irrigation with canal and tube well water in Punjab, India Irrig. Sci., 28: 489- 496.

Yang, C.J.; Y. Luo; L. Sun and N. Wu (2015). Effect of deficit irrigation on the growth, water use characteristics and yield of cotton in arid Northwest China. Pedosphere. 25 (6): $910-924$. 


\section{تأثير إدارة مياه الري ومصادر التسميد النيتروجيني على إنتاجية المياه وجودة بعض اصناف القطن المصري التروي \\ محمود محمد السيد '، ياسر عبد الصبور محمد خليفةّ، احمد محمد محمود الجلالى؟}

' أستاذ مساعد بقسم الأر اضي و المياه ـ كلية الزر اعة ـ جامعة الأزهر بأسيوط ـ مصر.

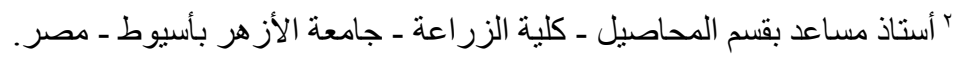

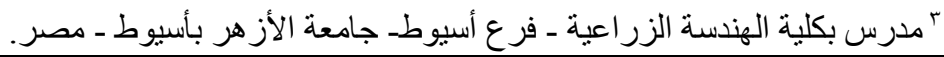

\section{الملخص العربى}

أجريت تجربة حقلية فى المزرعة البحثية لكلية الزراعة جامعة الأزهر، اسيوط،

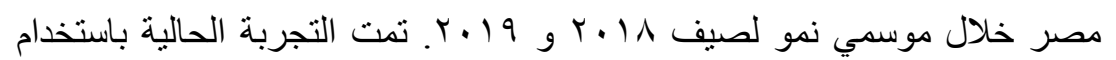
تصميم القطاعات كاملة العشوائية بترثيب القطع المنشقة ثلاث مرات في في ثناث مكررات فى تربة طميية طينية. تهدف هذه الدراسة إلى تقييم طرق الري المختلفة (الري فى الخطوط التقليدي و التبادلي) ومصادر التسميد النيتروجيني (اليوريا سماد نيتروجيني سريع الذوبان و اليوريا فورم سماد نيتروجيني بطئ الذوبان). وذللك وهئ لتعظيم إنتاج بعض أصناف القطن (جيزة • م وجيزة • 9). وكذلك تحديد أنسب طريقة

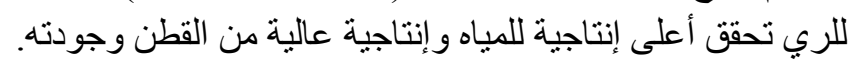

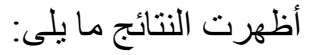
ا أظهرت النتائج أن الري بالخطوط التبادلية أدى إلى توفير ب إن من البخر نتح

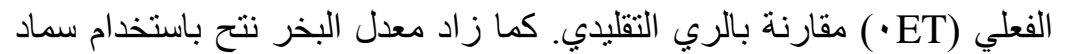
اليوريا مقارنة باستخدام اليوريا فورم كما اظهرت النتائج فروق غير معنوية بين

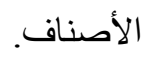

ب ب. تم اتباع الترتيب التنازلي لقيم البخر نتح المقدرة فى كلا الموسمين - Penman ع. و أظهرت معادلة هارجريفز كفاءة

$$
\text { عالية فى حساب ET }
$$

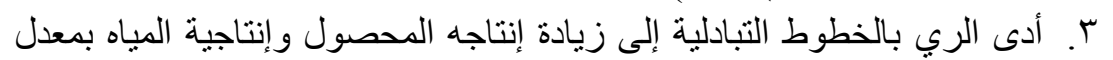

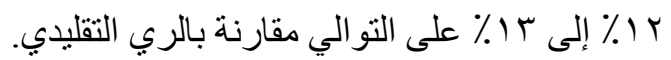

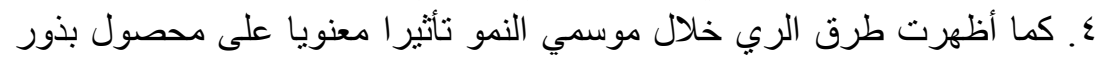

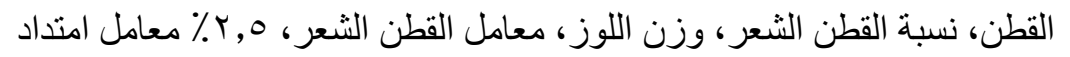
الطول، نسبة انتظام الطول، متانة الألياف (مؤشر Pressly)، ونعومه الطونة الألياف، اعطت أعلى نتائج تحت الري بالخطوط التبادلية.

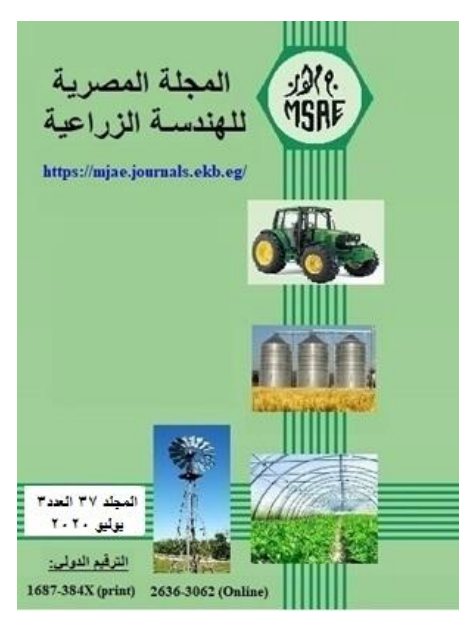

(C) المجلة المصرية للهندسة الزراعية

الكلمات المفتاحية: البخر نتح، الاستهلاك المائي، إنتاجية المياه، جودة المحصول، القطن. 